\title{
Education and Sustainability: The Case of Emotions Park
}

\author{
Angela Dettori ${ }^{1}$, Federica Caboni ${ }^{1} \&$ Ernestina Giudici ${ }^{1}$ \\ ${ }^{1}$ Department of Economics and Business Science, University of Cagliari, Italy \\ Correspondence: Angela Dettori, Department of Economics and Business Science, University of Cagliari, Italy. \\ E-mail: angela.dettori@unica.it
}

$\begin{array}{ll}\text { Received: August 28, } 2017 & \text { Accepted: September 22, 2017 Online Published: October 25, } 2017 \\ \text { doi:10.5539/jms.v7n4p65 } & \text { URL: http://doi.org/10.5539/jms.v7n4p65 }\end{array}$

\begin{abstract}
Firms working in the third millennium have to face the challenge of being more sustainable. The complexity and the multidisciplinary nature of sustainability also requires new and specific knowledge. This means the necessity of a critical rethinking of the education system in the way to provide the cognitive tools and applications needed for new generations to address environmental, economic, and social challenges. In this perspective, the role of the school it is crucial, above all, to encourage attention to include sustainability as a theme on educational programs, focusing on the promotion of its multiple dimensions. Interdisciplinary sustainability programs are emerging globally, but little is known about the learning in these educational contexts.

Therefore, the current research explores training modules used in the activities of a park to verify how students can receive a sustainable education from primary school; whether and in which way education can be a driver for the promotion of sustainable development; and whether it is effective to insert eco-activities such as eco-games, eco-campus, and eco-sports in the training modules from primary school onwards. For this purpose, the paper employed a single case study approach using the Emotions Park as a teaching plan. In particular, game and sports constantly accompany the training process by creating interdisciplinary links with different study subjects (e.g., civic education, environmental education, communication). Through the eco-activities, an innovative way to promote environmental and sustainability education was explored as a training model. Outdoor play, observation, and stimulation of the senses have proved powerful learning tools, and key to the acquisition of skills. Research data were collected observing the behavior of a sample of 22 participants and through face-to-face semi-structured interviews with educators, employee and students. The empirical observation suggests that inserting the sustainability principles as a topic in didactic programs provides the cognitive tools and applications needed for the new generations to address environmental, economic, and social challenges.
\end{abstract}

Keywords: education, sustainability, eco-activities

\section{Introduction}

Sustainability is based on the simple principle: everything that we need for our survival and well-being depends, either directly or indirectly, on our natural environment. Sustainability creates and maintains the conditions under which humans and nature can exist in productive harmony, that permit fulfilling the social, economic and other requirements of presents and future generations (Adams, 2006).

To achieve these conditions, sustainable individuals generate terms that allow an equitable access to the use of natural, environmental, social, economic, political and cultural resources (Ehrlich \& Ehrlich, 2009); their consumption of these resources is moderate (De Young, 1996; Iwata, 2001), allowing everybody to have access to them. Sustainably-oriented people are also cooperative and assist others in case of need (Pol, 2002), which means that they are "altruistically" motivated (Schultz, 2001). In addition, education plays a paramount role in the emergence and support of environmental dynamics, which is why a fundamental shift in people's behavior is required (Oskamp, 2000).

Given the increasing prominence of education and sustainability in academic debates, this work presents the various aspects of these concepts and considers the possible synergies between them. More specifically, the aim of this study is to understand:

1) How can students receive a sustainable development education beginning in primary school?

2) Can education and teaching be a driver for the promotion of sustainable development?

3) Is it effective to insert eco-activities in the training modules from primary school onward? 
In order to find answers to the above research questions, the eco-activities (eco-games, eco-sports and eco-campus) were analyzed after they were conducted within Emotions Park; the activities aimed to promote sustainable development by focusing on environmental and sustainability education. More specifically, these activities were mainly aimed at teachers of elementary and middle school students.

This paper is organized as follows. First, a review of the literature concerning sustainability and education is provided. Second, the methodology applied is explained, and the results are then described. Finally, concluding remarks and some implications for education practice are presented.

\section{Literature Review}

\subsection{Sustainable Development and Sustainability}

The core idea of sustainable development was defined most influentially by the World Commission on Environment and Development (WCED, 1987) as "development which meets the needs of the present without compromising the ability of future generations to meet their own needs" (p. 43). The above definition is adopted in this paper because, first, in its broadest sense, this normative abstraction has been widely accepted and endorsed by thousands of governmental, corporate, and other organizations worldwide (Gladwin et al., 1995; Baker, 2016), and second is the definition adopted by the United Nations (UN).

The sustainable development is considered by some authors as multi-dimensional, incorporating different aspects of society, seeking environmental protection and maintenance of natural capital to achieve economic prosperity and equity for present and future generations (Kelly et al., 2004).

For other scholars, the sustainable development is seen as: the maintenance of essential ecological processes, preservation of genetic diversity and sustainable use of species and ecosystems (Tisdell, 1988); equal opportunities for future generations (Chichilnisky, 1996), a process of change in which the exploitation of resources, the direction of investments, orientation of technological and institutional change are made according to the future, considering present needs (Hove, 2004).

Over time, the notion of sustainable development has evolved as an integrating concept, an umbrella under which a set of inter-related issues can be gathered. This is a variable process of change that seeks the ultimate goal of sustainability itself. In the same context, sustainability is the ability of a human, natural or mixed system to resist or adapt to endogenous or exogenous change indefinitely (Dovers \& Handmer, 1992), represented as a goal or end point (Hove, 2004). Therefore, to achieve sustainability, sustainable development is required (Prug \& Assadourian, 2003).

According to Ayres (2008), sustainability is a normative concept about how humans should act in relation to nature, and how they are responsible for each other and future generations. In this context, it is noted that sustainability is conducive to economic growth based on social justice and the efficient use of natural resources (Lozano, 2012).

Often, sustainability is seen at two different levels: weak sustainability or strong sustainability. Weak sustainability can be interpreted as the extension of economic welfare (Neumayer, 2003), therefore, the economic capital produced by current generations can compensate for loss of natural capital for future generations (Fiorino, 2011). In contrast, strong sustainability is a paradigm of non-substitutability, in which there are natural systems that cannot be eroded or destroyed without compromising the interests of future generations (Fiorino, 2011).

If the existence of sustainability depends on their socioeconomic and environmental relationship, it can be seen as a major subject and addressed in different ways. Sachs (2002), for example, used eight types of sustainability (social, economic, ecological, spatial, territorial, cultural, national and international policy) to display the dimensions of what is called eco-development (p.96).

The concept of sustainability implies three different aspects or dimensions which: environmental, economic and social sustainability (Basiago, 1999; Munier, 2005). Generally, environmental sustainability can be described as environmental protection (Munier, 2005), and economic sustainability can be defined as economic growth and economic progress, although, as Munier asserts, "Economic growth does not necessarily mean a better living..." (p.17). Social sustainability is often related to problems such as poverty, social exclusion, unemployment, inequalities and the like not only in the present but also in the future (Ekins et al., 2008; Partridge, 2005). Moreover, on a general or basic level, can also be seen as: "A system of social organization that alleviates poverty, but in a more fundamental sense, however, social sustainability establishes the nexus between social conditions (such as poverty) and environmental decay..." (Basiago, 1999, p. 152).

Within the above dimensions, there is a lack of consensus on the terms sustainability and sustainable 
development. This is due to the fact that sustainability is used to describe the processes and activities (for example, sustainable finance, sustainable business, among others). In other cases, the activities aim to be sustainable, such as sustainable tourism, sustainable agriculture or sustainable buildings. Therefore, sustainable development mainly focuses on people and their well-being (Moldan et al., 2012).

Although there are several understandings, sustainability and sustainable development aim to pass on to future generations a stock of capital that is at least as large as our own generation has inherited from previous generations (Gaussin et al., 2013).

\subsection{Sustainable Development and Education}

Several studies that focus on education, learning and sustainable development have emerged in relation to the increasing recognition of the centrality of behavior to human beings (Foster, 2002; Vare \& Scott, 2007). Sen (1999) considers education as the basic component for a truly sustainable socio-economic development. If it is true that human beings are central in sustainable development, then similarly this development may be achieved only if education becomes a component of the environment-economy-society concept.

The education centrality in the pursuit of sustainable development has been clearly highlighted by Kofi Annan (Secretary General for the United Nations) that stated "Our biggest challenge in this new century is to take an idea that seems abstract—sustainable development—and turn it into a reality for all the world's people" and by Koïchiro Matsuura (UNESCO's Director-General) "Education — in all its forms and at all levels—is not only an end in itself but it is also one of the most powerful instruments we have for bringing about the changes required to achieve sustainable development".

United Nations and UNESCO — its specialized agency for education for sustainable development (EDS) - began to give attention to this topic since 1992. The engagement continued with the UN Decade for ESD (2005-2014) and currently with a strong strategic program (Annan-Diab \& Molinari, 2017), the 2030 Agenda for Sustainable Development. The 2030 Agenda, composed by 17 Goals, is an ambitious challenge and particularly interesting by an educational point of view: in fact, also if only the Sustainable Development Goal 4 (assume inclusive and equitable quality of education and promote lifelong opportunities for all) is specifically devoted to education, it clearly permeated all the others Goals. In the document "Education for Sustainable Development Goals: Learning objectives" (UNESCO, 2017), this strong interdependence between the Goal 4 and the others clearly emerged.

The global communities and particularly the UNESCO engagement contributed to strongly highlight the relationship between sustainable development and education and the need that schools be more attentive to transfer to their students the awareness that sustainable development will not be possible to forget (Weybrecht, 2017).

Moreover, in the 2030 Agenda emerge also a clear interest for education for sustainable development in the early childhood years. The value to start early with education for sustainability is clear: the early childhood years are the time of the greatest and most significant developments in a person's life (Davis, 2009; Mustard, 2000).

Another challenge that affect the world from several decades is change. Scott \& Gough (2003, pp. 113-116) identified three types of approaches that link the concepts of sustainable development, education and change:

- the first approach assume that the problems humanity faces are essentially environmental, can be understood through science, and resolved by appropriate environmental and/or social actions and technologies. It is assumed that learning leads people to change their mind once facts have been established and are told what they are;

- the second approach assumes that our fundamental problems are social and/or political, and that these problems produce environmental symptoms. Such fundamental problems can be understood by means of anything from social-scientific analysis to an appeal to indigenous knowledge. The solution in each case is to bring about social change, where learning and education are tools to facilitate choice between alternative futures. These futures can be specified based on present-day knowledge. Both these approaches have a long history and are attractive to pressure groups that advocate a shift to sustainability;

- the third approach assumes that what is (and can be) known in the present is not adequate; desired "end-states" therefore cannot be specified. This means that any learning must be open-ended.

Makrakis (2011) defined education for sustainable development as the learning needed to maintain and improve our quality of life and the quality of life of generations to come. It concerns equipping individuals, communities, groups, businesses, and government to live and act sustainably, as well as giving them an understanding of the environmental, social and economic issues involved (Makrakis, 2011). Education for sustainable development represents a new vision of teaching and learning, a vision that helps people reconnect with nature by addressing 
the complexity and interconnectedness of sustainability issues such as poverty, peace and international understanding, sustainable consumption and production, environmental degradation, climate change, water protection, and health (UNESCO, 2005; UNESCO, 2017). This vision of education emphasizes a holistic, interdisciplinary, and cross-disciplinary approach to developing the competencies needed for building a sustainable future (Makrakis, 2011).

\section{Methodology}

A unique case study approach has been used to investigate how students can receive a sustainable education that begins in primary school, and verify if and how education and teaching can be a driving factor in promoting sustainable development. In this way, provide information that could improve the cognitive framework for training, developing and implementing sustainability programs in an organization and in primary school education modules.

Using a case study presents a reliable framework for exploring patterns of a training and education within an organization and its environment. As Yin (2012) noted case studies follow orderly field procedures to elicit information from participants and provide a holistic perspective that represents a critical test of the occurrence.

The technique adopted for the study involved the collection of data through the use of open-ended face-face interviews, which was predicated on the descriptive nature of a qualitative study. In this regard, Fairweather and Rinne (2012) suggest that a qualitative research uses experiential sampling to clarify meanings and descriptions of the event.

\subsection{Case Study: The Emotions Park}

In order to explore these issues, this paper adopts a case-study approach (Yin 2009; Eisenhardt \& Graebner, 2007; Siggelkow, 2007) that analyzes the "Emotions Park" as a teaching plan. In particular, game and sports regularly accompany the training process by creating interdisciplinary links with different study subjects (e.g., civic education, environmental education, communication).

The Emotions Park was born in August 2008 with a Sardinian Region (Italy) honor loan, and it is located within Regional Natural Park Molentargius-Saline (close to Cagliari, the Region Capital) and is considered the first adventure park in Sardinia.

This park is a place where students can live in an immersive experience during their visit by engaging with recreational sports equipment such as an adventure trail, a labyrinth of the senses, bouldering wall and several eco-activities or "eco-games".

The park's mission is related to the creation of sustainable land development, with particular attention to the environmental education of children/students education for sustainability. The park's philosophy is related to development of a closer consciousness to environment and to their territory and the acquisition of the concept of respect and environmental protection, in order to achieve a better quality of life and greater prosperity.

Students, during their visit can make different experiences e.g.: acrobatic route suspended, climbing wall and the labyrinth of senses all in a sustainable perspective (see Figure1, Figure 2).

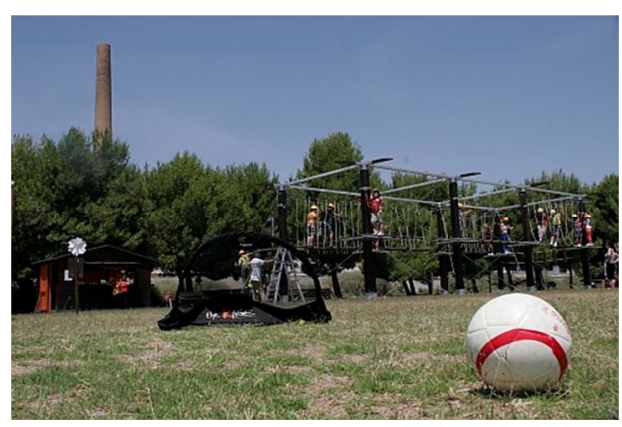

Figure 1. The acrobatic route suspended 


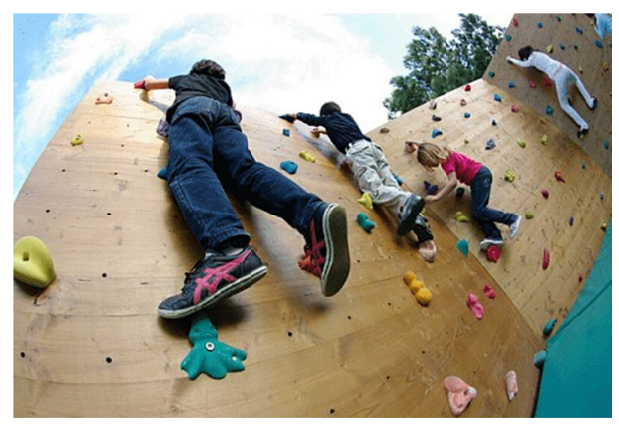

Figure 2. The climbing wall

Source: www.parcoemozioni.it

The eco-game offers the opportunity to experience an innovative way to live in nature with new sensations and emotions. These activities, conducted in the outdoors or in a corner of nature recreated in urban spaces, teach young people how to overcome obstacles offered by the environment in full respect of the same. In particular, sport within nature creates the opportunity to test their body with a sense of balance, agility, strength and speed, in order to become more aware of their own means.

It is useful to specify that the activity does not concern only a "visit" of the park but it is characterized by a specific program (as showed in figure 5) made in collaboration between teachers and park educators, that starts at school, with discussion on topics able to create a basic knowledge on sustainable environment, which continues in the Park with the full immersion on nature and the related emotions, and ends in class with some students consideration and activities stimulated by teachers that contains several means that can be considered pills of education towards the adoption of sustainable behaviors.

Another aspect concerned the strong collaboration between the park operators, schools and teachers: this kind of collaboration with a specific program of education and repeated "sustainable experiences" can determine responsible citizens in the future.

The overall goal of training modules has been to push the students to reflect on their habits and to create in each of them the awareness that a "sustainable behavior" is the key element in the resolution of environmental problems. The idea is to make the student feel part of a community that engages in a common effort for the protection of natural resources.

\subsection{Sampling Methods and Participants}

The selected 22 participants include 4 park employees, 4 park educators and 14 students. Participants selected for the study included experts in sustainability training modules to extract deep perceptions of the phenomenon and the sample was the most reliable way to bring out perceptions of experienced individuals. The participants provided information on the purpose of the study accepted it and voluntarily participated without any compensation.

In addition to interviews, we collected images and visited places where eco-games, eco-campus and eco-sport were performed. Finally, we participated in some training sessions and we observed the 14 students to gain a deeper understanding of the learning process.

\subsection{Data Analysis}

All participants interview responses were tape-recorded and transcribed for analysis. Data analysis began with analyzing the interview transcripts. Analyzing the content of the transcript enabled coding and emerging themes to describe segments of the data. The techniques for data analysis included interpretative analysis based on a descriptive framework.

The biggest challenge behind data analysis is to demonstrate the objectivity of the process through which the data and field notes are developed into conclusions (Eisenhardt, 1989; Miles \& Huberman, 1984; Van Maanen, 1988). The case study description is offered and the emerging constructs are delineated, and at this stage, detailed, descriptive write-ups are created. Despite being descriptive, such case write-ups are core to the creation of insights (Gersick, 1988; Pettigrew, 1990), although there are no standardized formats for such write-ups (Yin, 1989). Case write-ups are deemed to be analysis as a result of the decisions that researchers make as to what the emerging issues are and how they should be captured in the write-ups. To organize and analyze data we used "R", a professional and open source statistical software (www.r-project.org). 


\section{Results}

With using the software " $\mathrm{R}$ project", the results from the analysis of participants' perceptions regarding the concept of sustainability highlighted some relevant topics: education, collaboration and innovation (as shown in Graph 1).

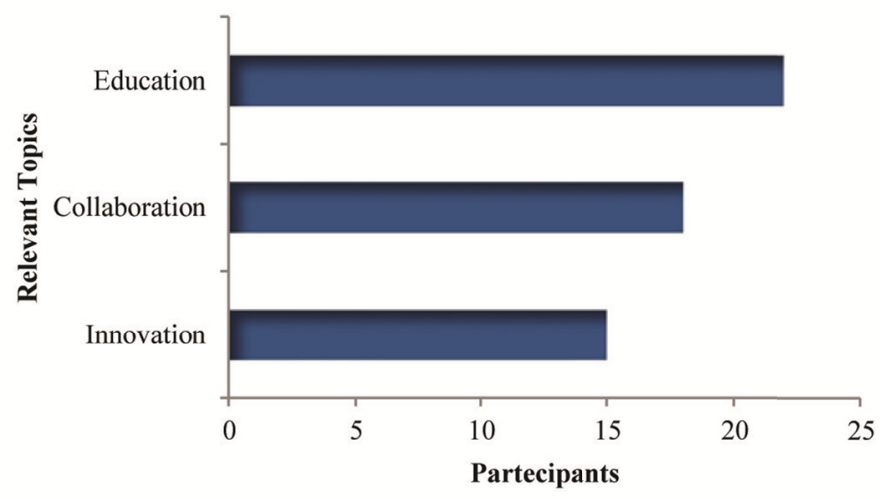

Graph 1. Relevant Topics

Source: Authors' elaboration with "R project" software.

Furthermore, this software has revealed the direct connections between other minor concepts as information, knowledge and change emerged from the analysis of participants' perceptions (as shown in Figure 3).

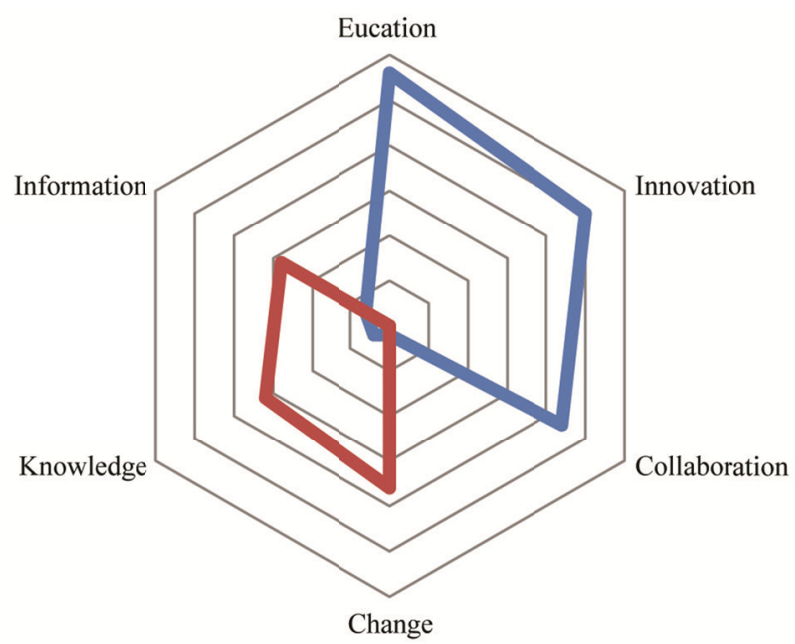

Figure 3. Connection between concepts

Source: Authors' elaboration with "R project" software.

The concepts emerging from the analysis of participants' perceptions on notion of sustainability are justified by the fact that, though education, collaboration and innovation play a key role in the transition process towards sustainability, the heritage of knowledge and information has not yet become an integral part of the teaching offer. Today, schools contribute to create this kind of awareness with the inclusion of some pills of sustainability in the training modules (Weybrecht, 2017). Learning and behavioral change are essential for achieving sustainable thinking and living (learning to live sustainably), which is inextricably connected to transformative perceptions of learning (Makrakis, 2012).

An innovative element that is emerged from the analysis is the "eco-games" embedded in the training modules for certain classes belonging to the primary school (see Figure 4). 


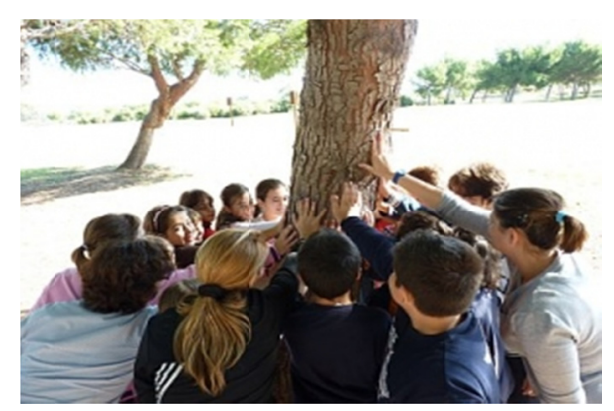

Figure 4. Teaching laboratory of sustainable development education

Source: www.parcoemozioni.it

In detail, three training modules were created, as shown in Figure 5:

SUSTAINABLE EDUCATION

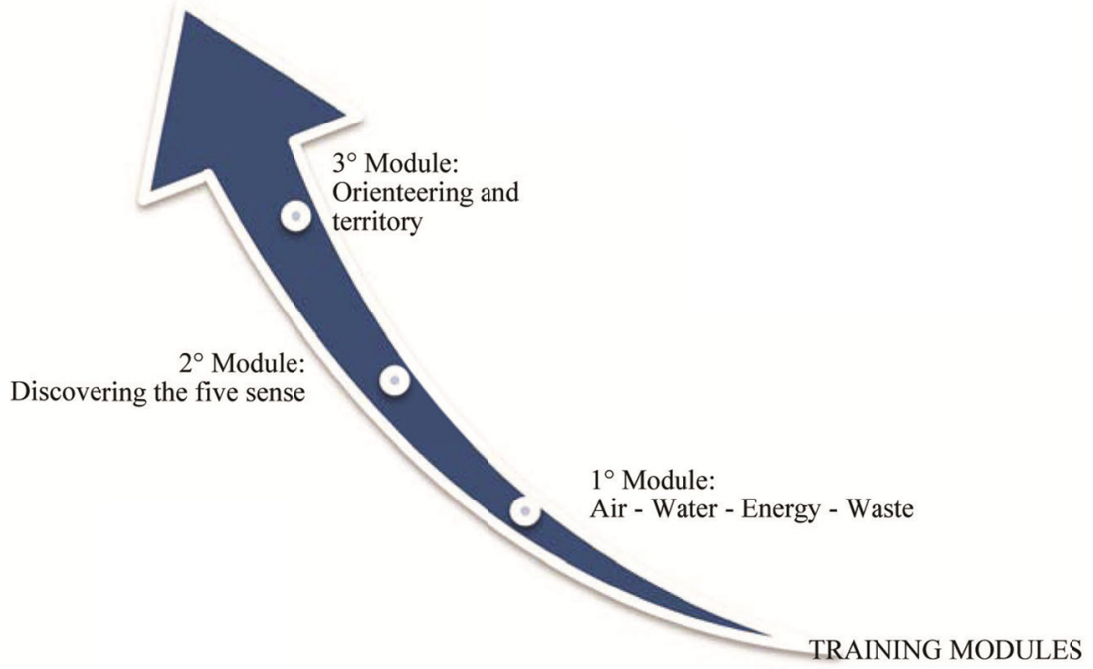

Figure 5. Training modules

The first module was aimed to memorize the three Rs: Reduce, Reuse, Recycle and to investigate the issue of limited resources and waste, develop a proper method for the selective collection, and promote sustainable living.

Several studies (Oskamp, 2000; O'Brien, 2010; O’Brien, 2012) have shown that "fun games" develop in children and young people a spirit of acute observation, criticism and awareness and conferring the possibility of a change in thinking and behaving.

As for the activities, the students solved environmental puzzles involving "waste, air, water, energy, sustainable behavior", thus testing their level of knowledge about the subjects. In the period that has separated the meeting at the park and the one in the classroom, the educators of park have asked students during their free time to capture with a camera interesting situations related to "water, energy, air and waste". In the classroom, however, the students will be asked to clean up the class by selecting the waste and calculating the ecological footprint.

At the end of trail have been created various elaborated: a) the waste manual; b) the top ten, accompanied by photos taken by small saviors of the world, behaviors to avoid and to bear to help the friend environment "healthy growth" (e.g., to remember to recycle waste, plant a tree, save water); c) environmental signs of prohibited, dangerous or obligation.

The second module provides for the rediscovery of the five senses. This was facilitated by the contact with nature, and encouraged the emergence of an alliance and friendship between student and territory.

This module has also been proposed for the disabled and has achieved its best results in joint participation. In 
this case, a highly social value provided a cultural experience of high value.

In the Park, the students, through the help of air routes, a bouldering wall and a labyrinth, were challenged to solve puzzles with their senses and to perform interesting activities aimed at overcoming phobias such as fear of the void, the dark and narrow spaces.

For one game, the students were asked to pretend to smell like a hunting dog. For others, they were asked to listen carefully, to watch a game, and to learn "to see" with their hands and feet. The training course has separately stimulated the use of the senses, has developed and honed perceptual skills, taught the students to approach the world more closely, to explore the outside rather than even their inner dimensions, emotional and affective.

After the meetings classes have, with the help of teachers, created the album of "senses" (e.g., "feel a smell", "feel a color", "you hear a sound, "feel a taste").

The third module aimed to convey a culture that, through study and the graphic representation of the different environments, teaches respect and the conservation of natural resources. As educational process, that module responds to the need to give continuity to the process of maturation of the personality in its physical and intellectual component.

The orienteering, or "sport of the woods" activity, was carried out through a process realized with the help of a map and a compass, choosing the best way forward to achieve the desired points. The starting point of the activities was the school environment (such as a student's desk, room, classroom, gym), where the students learned to read the paper and the use of the compass through a game. This form developed sense of direction, cooperative work, observation, perception, representation of space, attention and memory.

Moreover, the different modes of cartographic representation, knowledge of the operation of the compass, and orientation techniques were analyzed.

The resolution of the gaming tests and a final test constituted the verification of the expected results. Finally, students realized several elaborate projects such as a custom map of the school, the park and the country.

After attending training modules, students have acquired the knowledge of many concepts and tools useful to address the sustainability challenges (see Graph 2.). This is a useful example (to imitate) that highlights how education and teaching can be a driver for the promotion of sustainable development and suggesting the inclusion of sustainability principles as a theme in education programs.

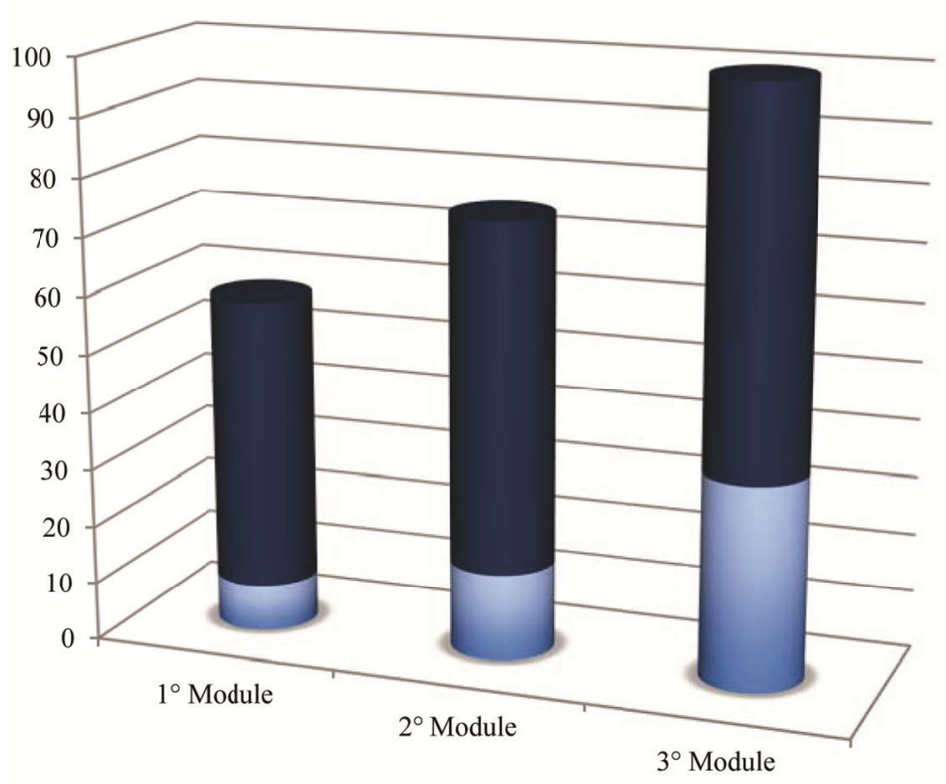

- After Training Modules

ఐ Before Training Modules

Graph 2. Perception of Sustainability before and after training modules

Source: Authors' elaboration with "R project" software.

The previous observation is justified by the fact that at the end of the training modules has been repeated the 
question: How would you define the term sustainability? Participants were able to respond with greater awareness, linking and justifying the concepts that emerged earlier, despite the young age of the sample analyzed.

\section{Discussion and Conclusion}

Increasingly, today's lifestyle imposes on adults, teens and children challenging rhythms of programmed activities that conflict with the rhythms of nature and physical and human sanity.

The Emotions Park seeks to recover in children or students a learning and emotional relationship with the places of nature. Knowledge of the natural environment in all its aspects (as suggested by the Unesco's proposed activities) can be a stimulus to taste and curiosity to appreciate it as an important personal asset and collective, as well as an opportunity to experience the training modules in alternative and constructive way.

The primary school students who participated in this project were involved in physical, cognitive and emotional as eco-activities. Outdoor play, observation, and stimulation of the senses have proved powerful learning tools, and key to the acquisition of skills.

On the other side, teachers have been able to transfer to students the awareness that they can help create a more sustainable future world by integrating the training plan with the Park's eco-games.

To strengthen this goal, it is necessary expand the teaching offerings to include topics on sustainability (Annan-Diab \& Molinari, 2017) beginning in primary school (Davis, 2009) because learning and behavioral change are drivers for achieving sustainable thinking and living (i.e., learning to live sustainably), which is inextricably connected to transformative perceptions of learning (Makrakis, 2012).

The limits of this work concern, first, the youth of the analyzed in the park eco-activities, and second that we observed only one specific park working for the sustainable education.

The main practical implication of this study is that starting at primary school to educate students on sustainable behaviours, will be possible to have sustainable citizens and managers in the future.

As regards future research, the authors will be engaged to follow the Emotion Park development and to compare these eco-activities with similar ones around the world.

\section{References}

Adams, W. (2006). The future of sustainability: Re-thinking environment and development in the twenty-first century. The World Conservation Union. Report of the IUCN Renowned Thinkers Meetings. Retrieved from http:// cmsdata.iucn.org/ downloads/iucn_future_of_sustanability.pdf

Annan-Diab, F., \& Molinari, C. (2017). Interdisciplinarity: Practical approach to advancing education for sustainability and for the Sustainable Development Goals. The International Journal of Management Education, 15(2), Part B, 73-83. https://doi.org/10.1016/j.ijme.2017.03.006

Ayres, R. U. (2008). Sustainability economics: Where do we stand? Ecological Economics, 67(2), 281-310. https://doi.org/10.1016/j.ecolecon.2007.12.009

Baker, S. (20016). Sustainable development (2nd ed.). London: Routledge.

Basiago, A. D. (1999). Economic, social and environmental sustainability in development theory and urban planning practice. The Environmentalist, 19(2), 145-161. https://doi.org/10.1023/A:1006697118620

Chichilnisky, G. (1996). An axiomatic approach to sustainable development. Social Choice and Welfare, 13(2), 231-257. https://doi.org/10.1007/BF00183353

Davis, J. M. (2009). Revealing the research "hole" of early childhood education for sustainability: a preliminary survey of the literature. Environmental Education Research, 15(2), 227-241. http://dx.doi.org/10.1080/13504620802710607

De Young, R. (1996). Some psychological aspects of a reduced consumption lifestyle: the role of intrinsic satisfaction and competence motivation. Environment \& Behavior, 28(3), 358-409. http://dx.doi.org/10.1177/0013916596283005

Dovers, S. R., \& Handmer, J. W. (1992). Uncertainty, sustainability and change. Global Environmental Change, 2(4), 262-276. https://doi.org/10.1016/0959-3780(92)90044-8

Ehrlich, P. R., \& Ehrlich, A. H. (2009). The population bomb revisited. The Electronic Journal of Sustainable Development, 1(3), 63-71. Retrieved from http://www.populationmedia.org/wp-content/uploads/

Eisenhardt, K. M. (1989). Building theories from case study research. Academy of Management Review, 14(4), 
532-550. Retrieved from https://www.jstor.org/stable/258557?seq=2\#page_scan_tab_contents

Eisenhardt, K. M., \& Graebner, M. E. (2007). Theory building from cases: opportunities and challenges. Academy of Management Journal, 50(1), 25-32. https://doi.org/10.5465/AMJ.2007.24160888

Ekins, P., Dresner, S., \& Dahlstrom, K. (2008). The four-capital method of sustainable development evaluation. European Environment, 18(2), 63-80. http://dx.doi.org/10.1002/eet.471

Fairweather, J., \& Rinne, T. (2012). Clarifying a basis for qualitative generalization using approaches that identify shared culture. Qualitative Research, 12(4), 473-485. https://doi.org/10.1177/1468794111433000

Fiorino, D. J. (2011). Explaining national environmental performance: Approaches, evidence, and implications. $\begin{array}{lllll}\text { Policy Sciences, } & \text { 44(4), } & \text { R67-389. } & \text { Retrieved }\end{array}$ https://link.springer.com/article/10.1007/s11077-011-9140-8

Foster, J. (2002). Sustainability, higher education and the learning society. Environmental Education Research, 8(1), 35-41. http://dx.doi.org/10.1080/13504620120109637

Gaussin, M., Hu, G., Abolghasem, S., Basu, S., Shankar, M.R., \& Bidanda, B. (2013). Assessing the environmental footprint of manufactured products: A survey of current literature. International Journal of Production Economics, 142(2), 515-523. https://doi.org/10.1016/j.ijpe.2011.12.002

Gersick, C. (1988). Time and transition in work teams: toward a new model of group development. Academy of Management Journal, 31(1), 9-41. https://doi.org/10.2307/256496

Gladwin, T. N., Krause, T., \& Kennelly, J. J. (1995). Beyond eco-efficiency: towards socially sustainable business. Sustainable Development, 3(1), 35-43. https://doi.org/10.2307/256496

Hove, H. (2004). Critiquing Sustainable Development: A Meaningful Way of Mediating the Development Impasse? Undercurrent, 1(1), 48-54. Retrieved from http://dspace.africaportal.org/jspui/bitstream/123456789/23714/1/Critiquing\%20Sustainable\%20Developm ent $\% 20 \mathrm{~A} \% 20$ Meaningful $\% 20$ Way\%20of\%20Mediating\%20the\%20Development $\% 20$ Impasse.pdf?1

Iwata, O. (2001). Attitudinal determinants of environmentally responsible behavior. Social Behavior and Personality: An International Journal, 29(2), 183-190. https://doi.org/10.2224/sbp.2001.29.2.183

Kelly, R., Sirr, L., \& Ratcliffe, R. (2004). Futures thinking to achieve sustainable development at local level in Ireland. Foresight, 6(2), 80-90. https://doi.org/10.1108/14636680410537547

Lozano, R. (2012). Towards better embedding sustainability into companies' systems: an analysis of voluntary

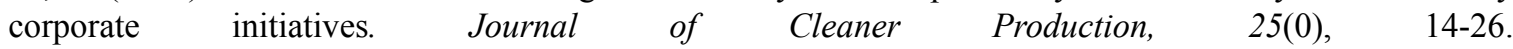
https://doi.org/10.1016/j.jclepro.2011.11.060

Makrakis, V. (2011). Strategies for change towards sustainability in tertiary education supported by ICT. In ICT in teacher education: Policy, open educational resources and partnership (pp. 152-166). Moscow: UNESCO Institute for Information Technologies in Education. Retrieved from http://unesdoc.unesco.org/images/0019/001936/193658e.pdf

Makrakis, V. (2012). Critical issues for the course curricular design and development of post- graduate programmes. In Proceedings of International Forum. "Modern Information Society Formation: Problems, Perspectives, Innovation Approaches" (pp. 85-107). Saint PetersburgStateUniversity of Aerospace Instrumentation 5-10 September.

Miles, M., \& Huberman, A. M. (1984). Qualitative Data Analysis. Beverly Hills, CA.: Sage Publications.

Moldan, B., Janouakovà, S., \& Hàk, T. (2012). How to understand and measure environmental sustainability: Indicators and targets. Ecological Indicators, 17, 4-13. https://doi.org/10.1016/j.ecolind.2011.04.033

Munier, N. (2005). Introduction to sustainability: Road to a better future. Dordrecht: Springer. Retrieved from http://www.springer.com/gp/book/9781402035562

Mustard, F. (2000). Early childhood development: the base for a learning society. Paper presented at the HRDC/OECD Meeting, December 7, in Ottawa, Canada.

Neumayer, E. (2003). The determinants of aid allocation by regional multilateral development banks and united nations agencies. International Studies Quarterly, 47(1), 101-122. https://doi.org/10.1111/1468-2478.4701005

O'Brien, C. (2010). Sustainability, happiness, and education. Journal of Sustainability Education, 1. Retrieved from http://sustainablehappiness.ca/wp-content/uploads/2012/12/Sustainability-Happ-Educ_JSE.pdf 
O'Brien, C. (2012). Sustainable happiness and well-being: future directions for positive psychology. Psychology, 3(12), 1196-1201. https://doi.org/10.4236/psych.2012.312A177

Oskamp, S. (2000). A sustainable future for humanity? How can psychology help? American Psychologist, 55(5), 496-508. http://dx.doi.org/10.1037/0003-066X.55.5.496

Partridge, E. (2005). Social sustainability: a useful theoretical framework, paper presented to the Australasian Political Science Association Annual Conference, Dunedin, New Zealand. Retrieved from http://www.academia.edu/3678834/Social_sustainability_a_useful_theoretical_framework

Pettigrew, A, (1990). Longitudinal field research on change: theory and practice. Organization Science, 1(3), 267-292. https://doi.org/10.1287/orsc.1.3.267

Pol, E. (2002). The theoretical background of the city-identity-sustainability network. Environment \& Behavior, 34(1), 8-25. https://doi.org/10.1177/0013916502034001002

Prugh, T., \& Assadourian, E. (2003). What is sustainability, anyway? World Watch, 16(5), 10-21. Retrieved from http://www.worldwatch.org/system/files/EP165A.pdf

Sachs, I. (2002). Caminhos para o desenvolvimento sustentável. $2^{\circ}$ Ed.: Rio de Janeiro: Garamond.

Schultz, P. W. (2001). The structure of environmental concern. Concern for self, other people, and the biosphere. Journal of Environmental Psychology, 21(4), 327-339. http://dx.doi.org/10.1006/jevp.2001.0227

Sen, A. (2009). Development as freedom. Oxford: Oxford University Press. https://doi.org/10.1007/978-1-137-28787-8_94

Siggelkow, N. (2007). Persuasion with case studies. Academy of Management Journal, 50(1), 20-24. https://doi.org/10.5465/AMJ.2007.24160882

Tisdell, C. (1988). Sustainable development: differing perspectives of ecologists and economists, and relevance to LDCs. World Development, 16(3), 373-384. https://doi.org/10.1016/0305-750X(88)90004-6

United Nations (1987). Our common future. Report of the World Commission on Environment and Development. Oxford, England: Oxford University Press.

United Nations Educational, Scientific and Cultural Organisation-UNESCO. (2005). Guidelines and recommendations for reorienting teacher education to address sustainability, UNESCO education for sustainable development in action. Technical Paper No. 4. Paris: UNESCO.

United Nations Educational, Scientific and Cultural Organisation-UNESCO. (2017). Education for Sustainable Development Goals. Learning Objectives. Paris, 07 SP France. http://www.opengovernment.org.uk/wp-content/uploads/2017/02/Education-for-Sustainable-DevelopmentGoals-Learning-Objectives.pdf

Van Maanen, J. (1988). Tales of the Field: On Writing Ethnography. Chicago: University of Chicago Press.

Vare, P., \& Scott, W. (2007). Learning for a change: exploring the relationship between education and sustainable development. Journal of Education for Sustainable Development, 1(2), 191-198. http://dx.doi.org/10.1177/097340820700100209

Weybrecht, G. (2017). From challenge to opportunity-Management education's crucial role in sustainability and the Sustainable Development Goals-An overview and framework. The International Journal of Management Education, 15(2), Part B, 84-92. https://doi.org/10.1016/j.ijme.2017.02.008

Yin, R. K. (1989). Case Study Research: Design and Methods. New-bury Park, CA: Sage Publications.

Yin, R. K. (2009). Case Study Research. Design and methods. Thousand Oaks: Sage.

Yin, R. K. (2012). Applications of case study research (3rd ed.). Thousand Oaks CA: Sage.

\section{Copyrights}

Copyright for this article is retained by the author(s), with first publication rights granted to the journal.

This is an open-access article distributed under the terms and conditions of the Creative Commons Attribution license (http://creativecommons.org/licenses/by/4.0/). 